\title{
Porphyrobacter neustonensis gen. nov., sp. nov., an Aerobic Bacteriochlorophyll-Synthesizing Budding Bacterium from Fresh Water
}

\author{
JOHN A. FUERST, ${ }^{*}$ JOHN A. HAWKINS, ${ }^{1}$ ANDREW HOLMES,${ }^{1}$ LINDSAY I. SLY, ${ }^{1}$ \\ CHRIS J. MOORE, ${ }^{2}$ AND ERKO STACKEBRANDT ${ }^{1}$ \\ Centre for Bacterial Diversity and Identification, Department of Microbiology, University of Queensland, \\ Brisbane, Queensland 4072, ${ }^{1}$ and Animal Research Institute, Department of \\ Primary Industries, Yeerongpilly, Queensland 4105, ${ }^{2}$ Australia
}

\begin{abstract}
Four strains of orange- or red-pigmented bacteria isolated from freshwater surfaces were shown to synthesize bacteriochlorophyll under aerobic conditions. These strains shared unusual morphological features, such as acellular stalks, crateriformlike structures, and buds, with bacteria in the order Planctomycetales. However, comparisons of $16 \mathrm{~S}$ rRNA sequences showed them to be members of the $\alpha-4$ subdivision of the class Proteobacteria and most closely related to the marine aerobic bacteriochlorophyll-synthesizing bacterium Erythrobacter longus. They also differ from members of the Planctomycetales phenotypically in their synthesis of bacteriochlorophyll and possession of a peptidoglycan cell wall. They can be distinguished from $E$. longus on the basis of their 16S rRNA sequence, the $G+C$ content of their DNA, cellular fatty acid composition, and carbon substrate spectrum. A new genus, Porphyrobacter, with a single species, $P$. neustonensis gen. nov., sp. nov., is proposed for these strains. The type strain is ACM 2844.
\end{abstract}

Classical anoxygenic photosynthetic bacteria typically exhibit repression of bacteriochlorophyll synthesis under aerobic conditions. Strains of several bacterial genera have however been shown to synthesize bacteriochlorophyll under aerobic conditions. Such bacteria include Erythrobacter longus (12, 41), "Erythrobacter sibericus"' (61), Roseobacter litoralis and Roseobacter denitrificans (formerly Erythrobacter strain OCh 114) (40), Methylobacterium species (34), Rhodospirillum centenum (60), mutants of Rhodobacter sphaeroides $(19,44)$, and the stem-nodulating Rhizobium strain BTAi 1 (6). The hot-spring mat bacterium Heliothrix oregonensis may also synthesize bacteriochlorophyll aerobically under in situ conditions in nature, although this bacterium has not been grown in pure culture $(29,30)$. Microorganisms of this physiological type have been referred to as the aerobic photosynthetic bacteria, with exclusion of the cyanobacteria being understood (39). Some are capable of photophosphorylation and may even possess photosynthetic reaction centers, although they appear not to be phototrophic $(10,24,26,38,42,52)$.

We have isolated bacteria capable of synthesizing bacteriochlorophyll under aerobic conditions from fresh water. These bacteria thus bear superficial resemblance to Erythrobacter species including the marine $E$. longus and the freshwater " $E$. sibericus." However, our freshwater strains also share some morphological and ultrastructural features with a distinctive group of budding bacteria distant from the class Proteobacteria, the planctomycetes. They display budding reproduction in a similar manner to that seen in the planctomycetes, produce some form of noncellular multifibrillar stalk or fascicle, and possess negative stain-collecting pits in the cell surface, termed crateriform structures, thought to be specific to planctomycetes (36). The phylogenetic possibility thus arose that these bacteria might be related to a quite distinct phylum of eubacteria distant from the Proteobacteria and furthermore one in which bacterio-

\footnotetext{
${ }^{*}$ Corresponding author.
}

chlorophyll had never been found. With the exception of $H$. oregonensis, all of the named aerobic photosynthetic bacteria appear to be well-defined members of the $\alpha$ subclass of the Proteobacteria. It is known from 16S rRNA oligonucleotide cataloguing that $E$. longus is a member of the $\alpha$ subclass of the Proteobacteria, which includes many of the purple nonsulfur bacteria in addition to many nonphotosynthetic bacteria (59). E. longus represents the $\alpha-4$ subgroup as its only genus and species.

The phylogenetic relationships of the bacteriochlorophyllsynthesizing methylotrophic strains are complex and still relatively unexplored. On the basis of 16S rRNA sequencing, bacteriochlorophyll-synthesizing Methylobacterium strains (such as $M$. extorquens AM1) are not closely related to either the $\alpha-4$ subclass or Roseobacter spp. (56).

We present here evidence from ultrastructural, nutritional phenotype, bacteriochlorophyll spectral, and cellular fatty acid analyses and $16 \mathrm{~S}$ rRNA sequencing which supports the proteobacterial nature of the Australian freshwater budding aerobic bacteriochlorophyll-synthesizing bacteria and their separation from previously described aerobic bacteriochlorophyll synthesizers within the Proteobacteria. These bacteria constitute a novel distinct group within the $\alpha-4$ subdivision of the Proteobacteria, and the name Porphyrobacter neustonensis is proposed, establishing a new genus with one species in the $\alpha$ subdivision of the Proteobacteria.

\section{MATERIALS AND METHODS}

Culture media. The following culture media were used during isolation and in cultural and nutritional studies. (i) Peptone-yeast extract agar consisted of (per liter of distilled water) $10 \mathrm{~g}$ of peptone, $5 \mathrm{~g}$ of yeast extract, $5 \mathrm{~g}$ of $\mathrm{NaCl}$, and $15 \mathrm{~g}$ of agar; the $\mathrm{pH}$ was adjusted to 7.2 , and the medium was sterilized by autoclaving at $121^{\circ} \mathrm{C}$ for $20 \mathrm{~min}$. (ii) Casitoneyeast extract agar consisted of (per liter of distilled water) $5.0 \mathrm{~g}$ of casitone, $1.0 \mathrm{~g}$ of yeast extract, and $15 \mathrm{~g}$ of agar; the $\mathrm{pH}$ was adjusted to 7.2 , and the medium was sterilized by autoclaving at $121^{\circ} \mathrm{C}$ for $15 \mathrm{~min}$. (iii) Lake water agar (LWA) 
was a modification of the LWA medium employed by Franzmann and Skerman (8) and consisted of $15 \mathrm{~g}$ of agar per liter of filtered lake water from University Lake, University of Queensland campus, Brisbane, Australia, sterilized by autoclaving at $121^{\circ} \mathrm{C}$ for $15 \mathrm{~min}$. (iv) Staley peptone-yeast extract-glucose agar was the PYG medium of Staley (49), with vitamin solution and Hutner's mineral salts made up according to Staley (50). Marine PYA is a modification of Staley PYG medium with $0.25 \mathrm{~g}$ of acetate liter ${ }^{-1}$ in place of glucose and made up in artificial seawater (20). (v) BMMV basal medium for carbon substrate utilization consisted of (per liter of distilled water) $20 \mathrm{ml}$ of Hutner's basal salts $(50)$, $10 \mathrm{ml}$ of Staley's vitamin solution (50), $0.25 \mathrm{~g}$ of $\left(\mathrm{NH}_{4}\right)_{2} \mathrm{SO}_{4}$, and $2.0 \mathrm{~g}$ of $\mathrm{KH}_{2} \mathrm{PO}_{4}$; the $\mathrm{pH}$ was adjusted to 7.0 to 7.1 before autoclaving. (vi) SM agar consisted of (per liter of artificial seawater of Lyman and Fleming [20]) $5 \mathrm{~g}$ of Soytone (Difco) and $1 \mathrm{~g}$ of yeast extract; the $\mathrm{pH}$ was adjusted to 7.2 , and the medium was sterilized by autoclaving at $121^{\circ} \mathrm{C}$ for 20 min. (vii) Schmidt medium III agar as described by Schmidt (37) was used with $1.5 \%$ agar.

Origin of strains. The marine strains E. longus $\mathrm{OCh} 101^{\mathrm{T}}$ and Roseobacter denitrificans OCh $114^{\mathrm{T}}$ were received from Tsuneo Shiba (University of Tokyo, Otsuchi, Japan). Three of the freshwater strains (ACM 2844 ${ }^{\mathrm{T}}$, ACM 2847, and ACM 2721 , deposited in the Australian Collection of Microorganisms, Department of Microbiology, University of Queensland) were isolated from University Lake, a eutrophic freshwater pond on the campus of the University of Queensland, Brisbane; a fourth strain, ACM 2508, was isolated from a swimming pool in a previous study (47). For isolation of the first three strains, sampling of the surface microlayers of the littoral zone of University Lake was performed by floating a sterile autoclaved hydrophilic Nuclepore polycarbonate membrane filter ( $47-\mathrm{mm}$ diameter, $0.4-\mu \mathrm{m}$ pore size) onto the water surface for a few seconds, retrieving the filter with sterile flat forceps into $10 \mathrm{ml}$ of sterile University Lake water, and spreading dilutions onto either peptone-yeast extract agar or LWA and incubating plates at $28^{\circ} \mathrm{C}$. Colonies were selected for restreaking onto peptone-yeast extract agar or casitone-yeast extract agar. ACM $2844^{\mathrm{T}}$ was derived from a peptone-yeast extract agar plate, and ACM 2847 and ACM 2721 were derived from LWA. ACM 2508 had been isolated by Sly and Hargreaves (47), using a Millipore Pseudomonas count water tester (Millipore Corporation, Bedford, Mass.).

Biochemical and nutritional tests. Motility on Staley PYG and casitone-yeast extract media was examined in wet mounts from 3-day cultures. Colony color was examined on casitone-yeast extract agar plates. Acid production from the fermentation of glucose was determined using Hayward's modification of the Hugh and Leifson medium (13) and gram-negative nonfermentative (GNNF) medium (32). Oxidase activity was determined by the method of Kovacs (17), and catalase production was determined with $3 \% \mathrm{H}_{2} \mathrm{O}_{2}$. The ability to hydrolyze Tween 80 was examined using the medium of Sierra (43). Gelatin and starch hydrolysis were tested as described by Skerman (45). Chitinase activity was tested by using solubilized chitin in an agar basal medium, and casein hydrolysis was examined on milk agar plates. The production of aminopeptidase was examined by using L-alanine $p$-nitroanilide-impregnated disks. The ability to grow at $10,20,28$, and $37^{\circ} \mathrm{C}$ was tested by using microtiter trays containing Staley PYG broth. The ability to grow anaerobically in the light was tested by the following protocol. An inoculum was prepared from 3-day $30^{\circ} \mathrm{C}$-incubated Staley PYG plates by suspending growth in PYG broth to visible turbidity. Kimax tubes containing $4 \mathrm{ml}$ of PYG broth were inoculated with $0.2 \mathrm{ml}$ of inoculum and incubated at room temperature in an anaerobic hood with a hydrogen- $\mathrm{CO}_{2}-\mathrm{N}_{2}$ atmosphere under incandescent tungsten lamp illumination. Tubes were also incubated anaerobically under dark conditions in a metal container and aerobically in the dark at the same temperature. Growth was determined by $A_{600}$ against a distilled water blank. For antibiotic sensitivity tests, inoculum was spread onto $20-\mathrm{ml}$ PYG agar plates by using sterile glass spreaders, antibiotic disks soaked in $500 \mu \mathrm{g}$ of penicillin $\mathrm{ml}^{-1}, 10 \mu \mathrm{g}$ of cycloserine $\mathrm{ml}^{-1}$, or $100 \mu \mathrm{g}$ of vancomycin $\mathrm{ml}^{-1}$ were placed onto the agar surface, and the plates were incubated at $30^{\circ} \mathrm{C}$ for 4 days before inhibition zone diameters were read.

The ability to use various carbon substrates as sole carbon and energy sources was examined by two different methods. For most substrates, microtiter trays were used and filtersterilized carbon substrates were added to a final concentration of $0.1 \%$ in BMMV medium. For inoculum preparation, growth from a 3-day culture grown on Staley PYG medium was washed twice and diluted to the absence of visible turbidity in sterile Milli-Q water. For most substrates, BMMV basal liquid medium was used as the growth medium in microtiter trays, and $10 \mu \mathrm{l}$ of inoculum was added to each well. For lactate, butyrate, and glycolate only, BMMV basal medium with $1.5 \%$ agar was used in plates and inoculated with $10 \mu \mathrm{l}$ of inoculum as a patch with no more than four patches per plate. Plates were incubated at $28^{\circ} \mathrm{C}$ for 7 days, and the results were read at 5 and 7 days. Growth was recorded as positive if microcolonies formed on the test substrate and not on a control plate consisting of distilled water plus BMMV agar.

DNA base composition analyses. DNA was extracted and purified by the method of Marmur (21). The DNA base composition was determined by using thermal denaturation and second-derivative plots (46).

Spectroscopy. In vivo spectra were determined with TSM buffer (44) from 3-day-old aerobically grown plate cultures. The cell suspension was sonicated with 1030 -s bursts with a Branson Sonifier cell disrupter 200. After removal of cell debris, the supernatant was examined spectrophotometrically on a Cary 2300 spectrophotometer.

In vitro spectra were determined by using methanol extracts of 3-day cultures grown aerobically on Staley PYG broth stirred at $250 \mathrm{rpm}$ with a magnetic stirrer; for bacteriophaeophytin spectra, samples were acidified by the addition of $0.25 \mathrm{ml}$ of $1 \mathrm{M} \mathrm{HCl}$ to $3 \mathrm{ml}$ of methanol extract. Spectra were recorded with a Hitachi 150-20 spectrophotometer.

Cell wall analysis. Cultures were grown on Staley PYG agar for 13 days at $30^{\circ} \mathrm{C}$ and then washed in $0.1 \mathrm{M}$ Tris buffer $(\mathrm{pH} 8)$ and stored as a washed pellet at $-20^{\circ} \mathrm{C}$. Frozen pellets were resuspended in TSM buffer ( $\mathrm{pH} \mathrm{7.7)} \mathrm{and} \mathrm{soni-}$ cated as described above. Sonicates were centrifuged at $12,000 \times g$ for $10 \mathrm{~min}$, and the cell wall pellets were stored at $-20^{\circ} \mathrm{C}$. Before analysis, cell pellets were washed three times with double-distilled water and freeze-dried.

Freeze-dried pellets of the crude cell wall preparations were hydrolyzed with $4 \mathrm{~N} \mathrm{HCl}$ at $115^{\circ} \mathrm{C}$ for $4 \mathrm{~h}$ in vacuo. Pelleted cell wall material was analyzed according to the method of Agabian and Unger (1), modified to use the hydrolysis procedure mentioned above. The procedure was adapted for use on a Dionex D500 amino acid analyzer using the sodium citrate buffer systems recommended by the Dionex manufacturer for protein hydrolysates.

$16 S$ rRNA sequencing. Sequence data were obtained both 
by using the reverse transcriptase (RT) method $(5,18)$ and by sequencing of $16 \mathrm{~S}$ rDNA polymerase chain reaction (PCR) products after amplification of $16 \mathrm{~S}$ rDNA (58), using primers in the vicinity of positions $343,516,690,787,907,1100$, 1392, and 1500 (according to the Escherichia coli map numbering of Brosius et al. [3]).

Amplification of the 16S rDNA was performed by PCR, using conserved regions $10-30$ and 1520-1540 as targets for the amplification primers. Template DNA was prepared by heating a cell suspension to $95^{\circ} \mathrm{C}$ for $10 \mathrm{~min}$ (33). PCR reaction products were purified by phenol and chloroform extraction and then precipitated with ethanol. After resuspension in water they were separated by electrophoresis on $0.6 \%$ agarose, and the DNA was recovered by freezesqueeze elution (53). After concentration by ethanol precipitation, the double-stranded products were used directly for sequencing (4).

Sequences were obtained for the freshwater bacteriochlorophyll-synthesizing isolates ACM $2844^{\mathrm{T}}$, ACM 2721, ACM 2847 and ACM 2508 and for the marine bacterioclorophyllsynthesizing reference strains E. longus OCh $101^{t}$ and Roseobacter denitrificans OCh $114^{\mathrm{T}}$. Sequences from ACM $2844^{\mathrm{T}}$, ACM 2721, E. longus, and Roseobacter denitrificans were aligned with reference sequences from members of the class Proteobacteria (27). Unambiguously alignable regions were compared, and evolutionary distances were calculated by using DNADIST (utilizing the Kimura algorithm) from the PHYLIP v3.2 phylogenetic analysis software package (7); such distances were then used to generate a phylogenetic tree, employing the FITCH treeing algorithm in the same package. Sequence positions are referred to according to the numbering system for $E$. coli of Brosius et al. (3).

Cellular fatty acid analysis. Cells for analysis were grown on Staley PYG medium (ACM 2508, ACM 2721, and ACM $2844^{\mathrm{T}}$ ), casitone-yeast extract agar (ACM 2847), or SM agar (E. longus $\mathrm{OCh} 101^{\mathrm{T}}$ and Roseobacter denitrificans $\mathrm{OCh}$ $114^{\mathrm{T}}$ ) for 2 days at $28^{\circ} \mathrm{C}$ aerobically in the dark. Cells were harvested after 2 days by suspension in $2 \mathrm{ml}$ of water and stored at $-20^{\circ} \mathrm{C}$ for further processing. Saponification of cells and methylation of fatty acids were performed according to the method of Moss et al. (22), with the modification that fatty acid methyl esters (FAMEs) were extracted in hexane-methyl $t$-butyl ether (1:1). Analysis of FAMEs was performed by gas chromatography via the HP 5898A Microbial Identification System (MIS; Microbial ID Inc., Newark, Del.) using for calibration the chemical standards recommended by the system manufacturers and the biological reference extracts of Xanthomonas maltophilia. The diunsaturated nature of 18:2 acids was established, and the identity of other FAMEs was confirmed by gas chromatography-mass spectroscopy (GC-MS).

Electron microscopy. Negative staining was performed on cells washed from agar plates with membrane-filtered distilled water. Cells were negatively stained on carbon-coated nitrocellulose-filmed grids with filtered $1 \%$ uranyl acetate directly or after a drop of suspension was first mixed with a drop of a bacitracin solution $\left(50 \mu \mathrm{g} \mathrm{ml}^{-1}\right)$. Cells for thin sectioning were fixed in filtered $3 \%$ glutaraldehyde in $0.1 \mathrm{M}$ sodium cacodylate $(\mathrm{pH} 7.0)$ at $0^{\circ} \mathrm{C}$ for $1 \mathrm{~h}$, enrobed in agarose, and cut into cubes. Agarose cubes were washed in cacodylate buffer before postfixation in $1 \%$ osmium tetroxide in cacodylate $\left(1 \mathrm{~h}, 0^{\circ} \mathrm{C}\right)$; this was followed by en bloc treatment with $1 \%$ aqueous uranyl acetate for $15 \mathrm{~min}$ and dehydration in ethanol before embedding in LR White resin, sectioning with an LKB ultramicrotome, and staining of sections with Reynold's lead citrate and uranyl acetate.

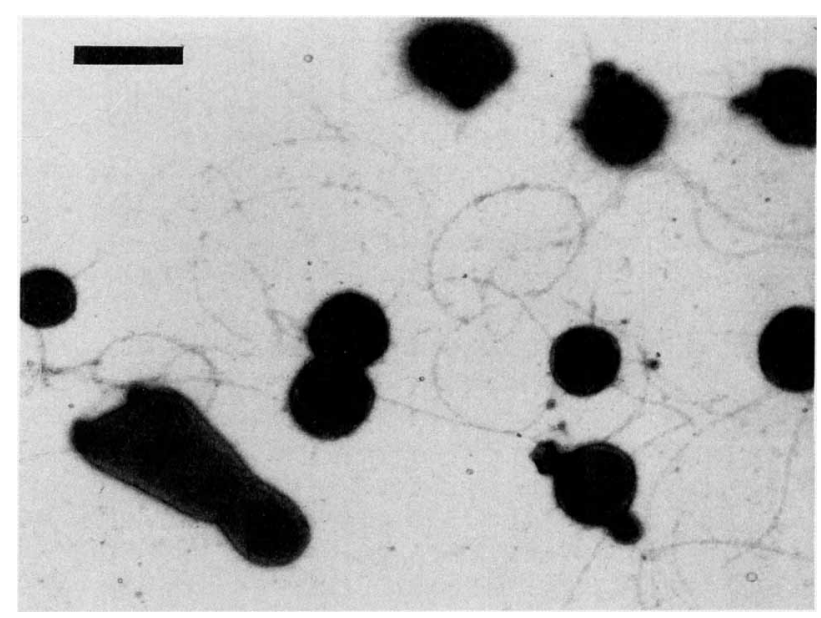

FIG. 1. Electron micrograph of ACM $2844^{\mathrm{T}}$, displaying pleomorphy and budding swarmer cells. Cells were grown on Schmidt medium III agar for 2 days at $28^{\circ} \mathrm{C}$ and negatively stained with $1 \%$ uranyl acetate. $\mathrm{Bar}=1 \mu \mathrm{m}$.

Sections were examined with a Hitachi $\mathrm{H}-800$ transmission electron microscope.

Nucleic acid sequence accession numbers. The 16S rDNA nucleotide sequence data reported in this paper for Porphyrobacter strain ACM 2721, Roseobacter denitrificans OCh $114^{\mathrm{T}}, P$. neustonensis ACM $2844^{\mathrm{T}}$, and E. longus OCh $101^{\mathrm{T}}$ have been submitted to GenBank and assigned accession numbers L01783 to $\mathrm{L} 01786$.

\section{RESULTS}

Morphology. Four strains of orange- to red-pigmented budding bacteria were isolated either from Nuclepore filterderived samples of the surface microlayer of a subtropical freshwater pond, University Lake (strains ACM 2844 ${ }^{\mathrm{T}}$, ACM 2847, and ACM 2721) or from the surface of a freshwater swimming pool (ACM 2508 [47]). Cells of these strains are pleomorphic, although they predominantly exhibit rod morphology. On certain media at least, coccoid and ovoid cells can be produced, especially by ACM $2844^{\mathrm{T}}$ (Fig. 1). Budding occurs in all strains and is predominantly polar in ACM 2844 ${ }^{\mathrm{T}}$, ACM 2721, and ACM 2508 but may be predominantly lateral in ACM 2847. All strains were motile when grown on Staley PYG agar, and, with the exception of ACM 2847, on casitone-yeast extract agar. Cells of all strains possessed subpolar or peritrichous flagella under permissive conditions.

The ultrastructure of the isolates is notable for several features shared with planctomycetes, namely budding, crateriform structures (circular pits visible on the surface of negatively stained cells), and noncellular multifibrillar stalklike (fascicle) structures (Fig. 1 to 4). Budding is often of a type found in planctomycetes, in which the daughter cell appears as a small spherical form (Fig. 1 and 3). Stalklike structures can be ropelike multifibrillar structures of twisted fibers, or, as in strain ACM 2721 (Fig. 2), dramatically cross-striated ribbonlike structures with distinct holdfastlike tips. The same strain may display both structures. Such stalklike structures are found only on some cells in a preparation. Crateriform structures are most apparent on some cells and buds of ACM 2847; those on the bud in Fig. 3 are 9 to $11 \mathrm{~nm}$ in outer diameter (4- to 6-nm inner diameter 


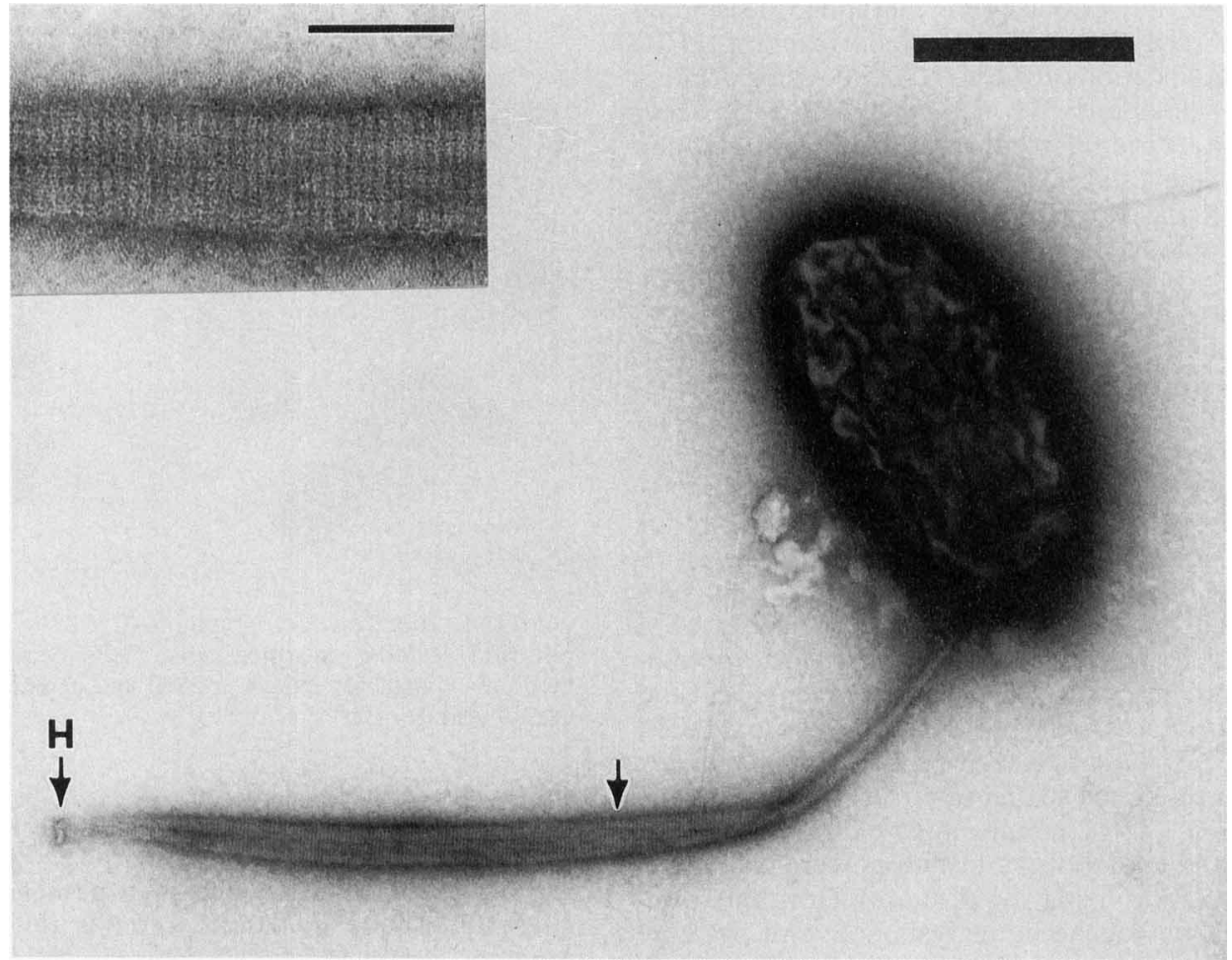

FIG. 2. Electron micrograph of ACM 2721 cell possessing a noncellular fibrillar striated stalk (arrow) with holdfast (H). Cells were grown for 2 days on Staley PYG Noble agar and stained with uranyl acetate. Bar $=0.5 \mu \mathrm{m}$. Inset shows an enlarged view of stalk; bar $=100 \mathrm{~nm}$.

of the electron-dense core). This can be compared with the diameter of $12 \mathrm{~nm}$ recorded for crateriform structures of planctomycete strain ICPB 4232, a morphotype IV planctomycete (54).

Thin sections of ACM $2844^{\mathrm{T}}$ indicate the presence of an electron-dense cell wall layer presumably representing peptidoglycan in the mother cell but the absence of an analogous electron-dense layer in the bud (Fig. 4).

Cell wall composition. Analysis of crude cell wall material isolated from all four isolates, ACM $2844^{\mathrm{T}}$, ACM $2847, \mathrm{ACM}$ 2721, and ACM 2508, indicated that muramic acid and diaminopimelic acid were both present, consistent with the presence of peptidoglycan in the cell wall and the occurrence of an electron-dense layer in thin sections of the cell wall in ACM $2844^{\mathrm{T}}$. Strain ACM $2844^{\mathrm{T}}$ possessed $0.0645 \mu \mathrm{mol}$ of muramic acid $\mathrm{mg}^{-1}$ and $0.139 \mu \mathrm{mol}$ of diaminopimelic acid $\mathrm{mg}^{-1}$, and strain ACM 2508 possessed $0.0563 \mu \mathrm{mol}$ of muramic acid $\mathrm{mg}^{-1}$ and $0.106 \mu \mathrm{mol}$ of diaminopimelic acid $\mathrm{mg}^{-1}$, while strains ACM 2847 and ACM 2721 possessed intermediate values for each compound per milligram (dry weight) of freeze-dried cell wall preparation. These data are consistent with gram-negative murein (15) and thus with thin-section data suggesting an electron-dense peptidoglycan cell wall layer (23).

Biochemical and nutritional characteristics. All of our isolates produce orange or red colonies, the intensity of pigmentation depending on the growth medium, casitoneyeast extract agar being the optimum for pigment production. The following carbon substrates were utilized as sole sources of carbon and energy by all four isolates: galactose, glucose, maltose, mannose, sucrose, xylose, arginine, glutamine, and proline. The following carbon substrates were used by none of the strains: arabinose, fucose, lactose,

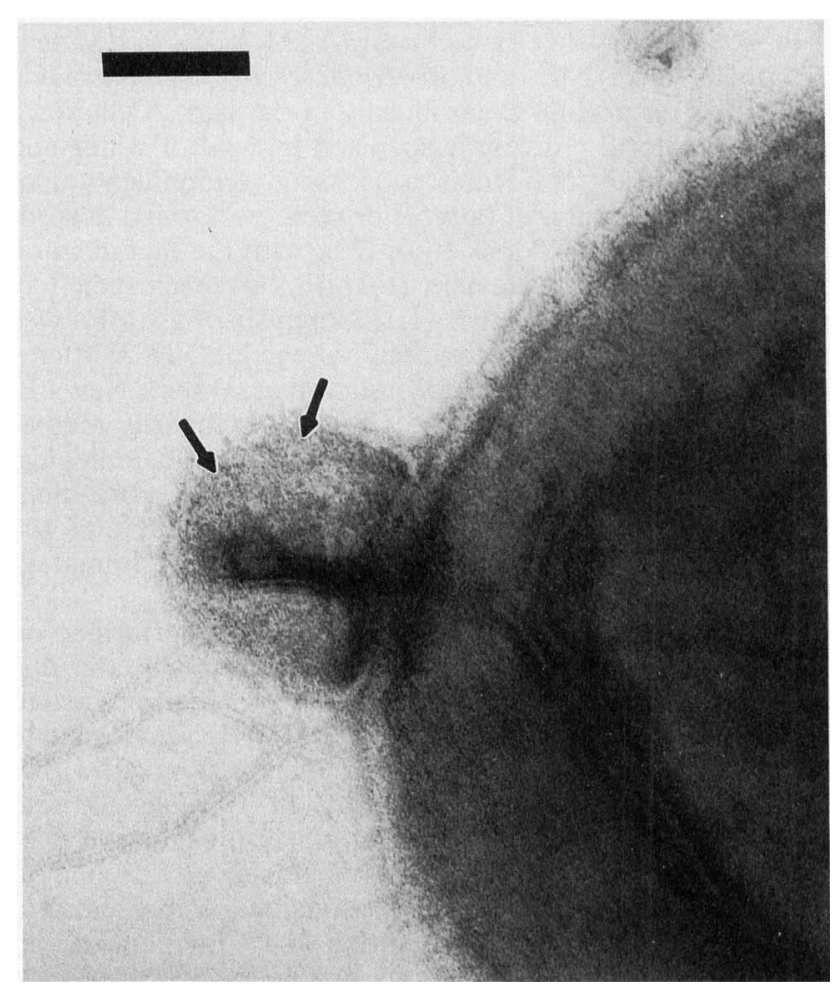

FIG. 3. Electron micrograph of ACM 2847 showing a bud with crateriform structures (arrows) over its surface. Cells were grown on Staley PYG agar for 2 days at $28^{\circ} \mathrm{C}$ and negatively stained with uranyl acetate. $\mathrm{Bar}=100 \mathrm{~nm}$. 


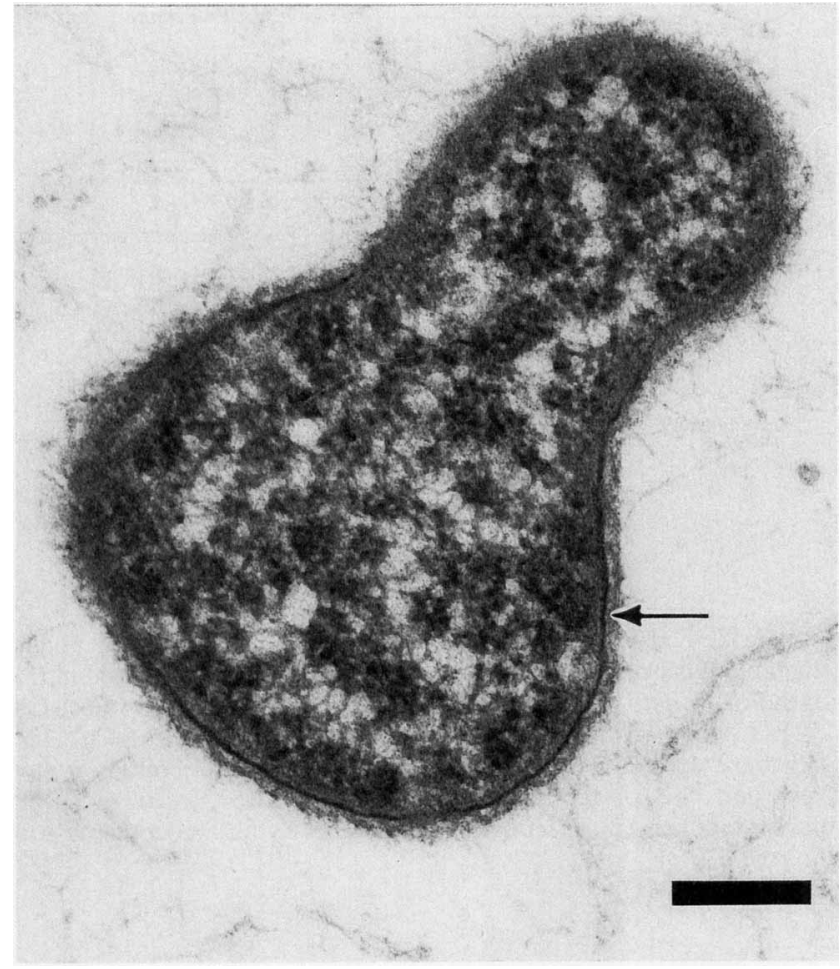

FIG. 4. Electron micrograph of a thin-sectioned cell of ACM $2844^{\mathrm{T}}$ grown on Schmidt III agar for 3 days at $28^{\circ} \mathrm{C}$, showing electron-dense layer (arrow) of wall present in mother cell only. Bar $=0.2 \mu \mathrm{m}$.

lyxose, $N$-acetylglucosamine, rhamnose, ribose, adonitol, arabitol, dulcitol, erythritol, sorbitol, aspartate, cysteine, glutamate, leucine, lysine, methionine, phenylalanine, tryptophan, tyrosine, valine, acetate, citrate, benzoate, caproate, caprylate, formate, lactate, butyrate, glycolate, $m$ hydroxybenzoate, $p$-hydroxybenzoate, L- $\alpha$-aminobutyrate, 4-amino- $\boldsymbol{n}$-butyrate, malate, phthalate, tartrate, ethanol, methanol, propan-2-ol, propan-1,2-diol, carnosine, and inulin. Results for carbon substrates for which utilization abilities varied with the strain are given in Table 1 . Of the C-1 compounds tested, only methylamine was utilized and only by one strain (ACM 2508). Chitin, gelatin, starch, and DNA were not hydrolyzed, but all the strains hydrolyzed Tween 80. Results for casein and esculin were variable (Table 1). All strains were fermentative as shown by acid production in sealed tubes if GNNF medium was used but were inactive if Hayward's modification of Hugh and Leifson medium was used. None of the strains produced gas from glucose in either Hayward's modification of Hugh and Leifson medium or GNNF medium. All strains were catalase positive and oxidase negative. None of the strains reduced nitrate. All strains grew between 10 and $37^{\circ} \mathrm{C}$ and grew on glucosemineral salts without added vitamins, on $0.1 \%$ peptone medium, and peptone-yeast extract agar. Other characters in which the strains varied are noted in Table 1 . However, none of the strains grew anaerobically in the light or the dark in the same medium (Staley PYG broth) supporting growth in aerobic dark conditions. All four strains were sensitive to vancomycin (9- to 15 -mm-diameter inhibition zones after 4 days of incubation) and resistant to cycloserine. Strains ACM $2844^{\mathrm{T}}$ and ACM 2508 were sensitive to penicillin,
TABLE 1. Biochemical and physiological characteristics which vary among Porphyrobacter strains

\begin{tabular}{|c|c|c|c|c|}
\hline \multirow[b]{2}{*}{ Characteristic } & \multicolumn{4}{|c|}{ Result for strain: } \\
\hline & $\begin{array}{c}\mathrm{ACM} \\
2508\end{array}$ & $\begin{array}{c}\text { ACM } \\
2721\end{array}$ & $\begin{array}{c}\mathrm{ACM} \\
2844\end{array}$ & $\begin{array}{c}\mathrm{ACM} \\
2847\end{array}$ \\
\hline \multicolumn{5}{|l|}{ Assimilation of: } \\
\hline Arabinogalactan & + & + & - & - \\
\hline Cellobiose & + & - & - & - \\
\hline Fructose & + & + & - & - \\
\hline Melezitose & -- & - & - & + \\
\hline Raffinose & + & + & - & + \\
\hline Trehalose & - & - & + & - \\
\hline Mannitol & - & - & + & - \\
\hline Alanine & + & + & + & - \\
\hline Asparagine & + & + & + & - \\
\hline Histidine & - & - & + & - \\
\hline Hydroxyproline & + & + & - & - \\
\hline Isoleucine & + & + & - & + \\
\hline Ornithine & + & + & + & - \\
\hline Serine & - & - & + & - \\
\hline Threonine & - & - & + & - \\
\hline Fumarate & - & - & - & + \\
\hline DL-Hydroxybutyrate & - & + & - & - \\
\hline Pyruvate & - & - & + & - \\
\hline Succinate & - & - & + & - \\
\hline Methylamine & + & - & - & - \\
\hline \multicolumn{5}{|l|}{ Hydrolysis of: } \\
\hline Casein & - & + & - & - \\
\hline Esculin & - & + & + & - \\
\hline Colony color ${ }^{a}$ & o & $\mathrm{r}$ & o & o \\
\hline $\mathrm{Mol} \% \mathrm{G}+\mathrm{C}$ & 66.3 & 65.7 & 66.4 & 66.4 \\
\hline
\end{tabular}

${ }^{a}$, orange; $\mathrm{r}$, red.

while strains ACM 2847 and ACM 2721 displayed only partial inhibition with penicillin.

Photosynthetic pigments. All strains produced bacteriochlorophyll $a$ (BChl $a$ ) when grown aerobically in the dark on Staley PYG medium, but production of this pigment was repressed on richer media such as casitone-yeast extract agar. Both in vivo and in vitro absorption spectra (Fig. 5 and 6 ) for extracts of all four isolates (ACM $2844^{\mathrm{T}}$, ACM 2847 , ACM 2721, and ACM 2508) displayed absorbance maxima characteristic for $\mathrm{BChl} a$. In vivo absorption spectroscopy of cell-free sonicates of the strains displayed peaks at 799 to 806

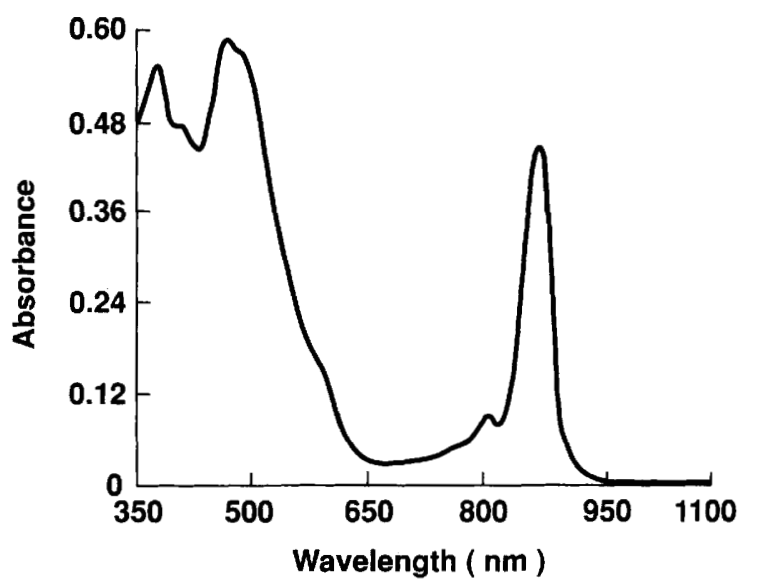

FIG. 5. In vivo absorption spectrum of sonicated cell extract of strain ACM 2721 showing characteristic BChl $a$ peaks at 799 and 870 nm. 


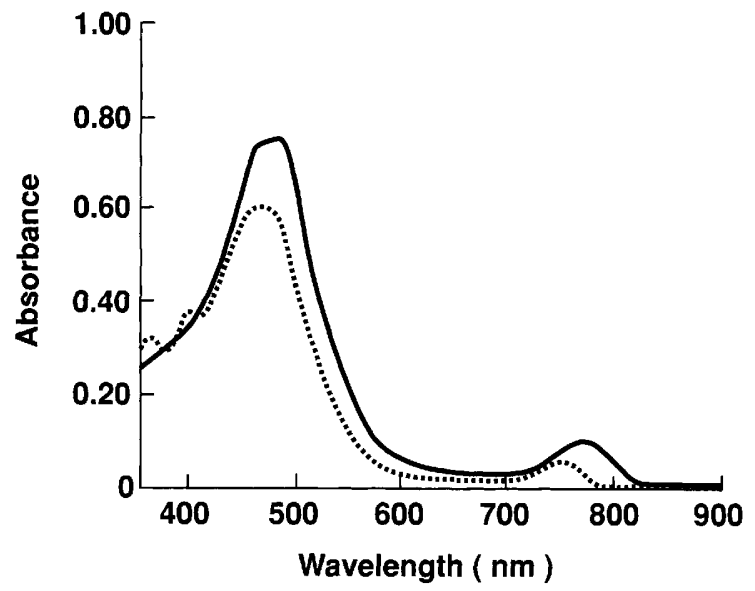

FIG. 6. In vitro absorption spectrum of methanol extract of $\mathrm{ACM} 2844^{\mathrm{T}}$ (continuous line) showing characteristic BChl $a$ peak at $768.8 \mathrm{~nm}$ and methanol extract of ACM $2844^{\mathrm{T}}$ cells acidified with $\mathrm{HCl}$ (dashed line) showing characteristic bacteriophaeophytin peak at $748 \mathrm{~nm}$.

$\mathrm{nm}$ and 868 to $871 \mathrm{~nm}$, characteristic for $\mathrm{BChl} \boldsymbol{a}$-protein complexes (28). Spectra for ACM 2844 ${ }^{\mathrm{T}}$, ACM 2847, and ACM 2721 also displayed Soret bands at $376 \mathrm{~nm}$, also characteristic of BChl $a$ (28). An in vivo spectrum for ACM 2721 is shown in Fig. 5. BChl $a$ presence was confirmed for all four isolates by in vitro spectra of methanol extracts of cells, which displayed a major peak at 768 to $769 \mathrm{~nm}$ (Fig. 6). A characteristic bacteriophaeophytin peak at $748 \mathrm{~nm}$ was demonstrated by all strains upon acidification of a methanol extract (Fig. 6 displays a spectrum for the type strain).

Cellular fatty acids. As can be seen in Table 2, the dominant fatty acid of our freshwater isolates and the marine reference strains E. longus OCh $101^{\mathrm{T}}$ and Roseobacter denitrificans OCh $114^{\mathrm{T}}$ was octadecenoic acid (18:1). ACM 2721 had a second major fatty acid, heptadecenoic acid $(17: 1)$. Roseobacter denitrificans was distinguished by the extremely high level of $18: 1$, with very few other detectable products. E. longus and strain ACM 2508 contained high

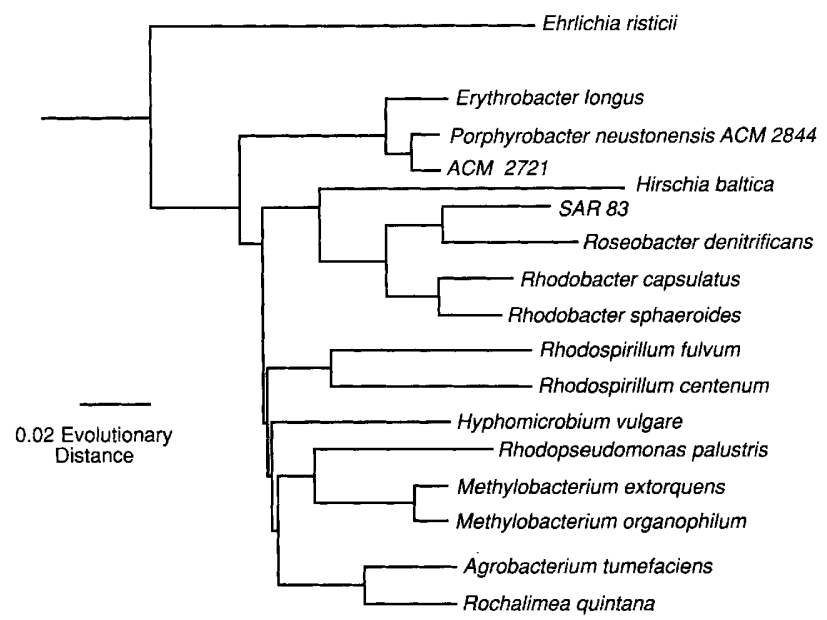

FIG. 7. Unrooted phylogenetic tree derived from unambiguously alignable positions of complete $16 \mathrm{~S}$ rRNA sequences derived in this study for $P$. neustonensis ACM $2844^{\mathrm{T}}$, Porphyrobacter strain ACM 2721, E. longus OCh $101^{\mathrm{T}}$, Roseobacter denitrificans $\mathrm{OCh} 114^{\mathrm{T}}$, data base-derived sequences for 12 reference Proteobacteria species, and the proteobacterial sequence SAR83, retrieved from marine biomass (2). E. coli was used as an outlier sequence to root the tree.

levels of octadecadienoic acid $(18: 2)$, which is rare in prokaryotes. E. longus also contained significant amounts of $16: 0$ and 17:1. Our isolates were similar to $E$. longus but could be distinguished by the higher levels of 3-hydroxy-isoundecanoic (3OHil1:0) and 2-hydroxytetradecanoic acid $(2 \mathrm{OH} 14: 0)$ and lower levels of hexadecanoic acid (16:0). Three of our isolates contained some level of octadecadienoic acid (18:2), which was not detectable in strain ACM 2721.

$16 S$ rRNA sequencing and phylogenetic analysis. Figure 7 shows the phylogenetic tree, displaying the relationship of two of our isolates, ACM $2844^{\mathrm{T}}$ and ACM 2721 , relative to certain members of the $\alpha$ subclass of the Proteobacteria. The dendrogram was derived from analysis of the almost

TABLE 2. Fatty acid composition of Porphyrobacter strains, E. longus, and Roseobacter denitrificans

\begin{tabular}{|c|c|c|c|c|c|c|}
\hline \multirow[b]{2}{*}{ Fatty acid } & \multicolumn{6}{|c|}{$\%$ of total fatty acids } \\
\hline & $\begin{array}{l}\text { Porphyrobacter } \\
\text { strain ACM } \\
2508\end{array}$ & $\begin{array}{l}\text { Porphyrobacter } \\
\text { strain ACM } \\
2721\end{array}$ & $\begin{array}{l}\text { Porphyrobacter } \\
\text { strain ACM } \\
2844\end{array}$ & $\begin{array}{c}\text { Porphyrobacter } \\
\text { strain ACM } \\
2847\end{array}$ & E. longus & $\begin{array}{l}\text { Roseobacter } \\
\text { denitrificans }\end{array}$ \\
\hline $\mathrm{n} 10: 0$ & 1.2 & 0.9 & 1.1 & 1.3 & $\mathrm{ND}^{a}$ & 1.4 \\
\hline 3-OH i11:0 & 2.4 & 1.0 & 1.2 & 1.6 & 0.3 & ND \\
\hline n14:0 & ND & ND & ND & 0.6 & ND & ND \\
\hline 2-OH n14:0 & 4.5 & 1.8 & 2.7 & 3.1 & 0.4 & ND \\
\hline n15:0 & 0.8 & ND & ND & 0.5 & 2.7 & ND \\
\hline 2-OH n15:0 & ND & 1.9 & ND & ND & 1.4 & ND \\
\hline $\mathrm{n} 16: 0$ & 4.0 & 2.7 & 2.6 & 5.0 & 9.4 & 3.7 \\
\hline 3-OH i16:0 & ND & ND & 0.7 & ND & ND & 0.7 \\
\hline n16:1 & 1.9 & 1.8 & 0.9 & 2.3 & 0.7 & ND \\
\hline n17:0 & ND & 1.6 & ND & ND & 11.0 & ND \\
\hline i17:0 & ND & ND & ND & ND & 1.6 & ND \\
\hline n17:1 & ND & 32.0 & ND & 5.5 & 5.5 & ND \\
\hline n18:0 & 1.2 & ND & ND & ND & 0.4 & 3.4 \\
\hline n18:1 & 71.7 & 47.0 & 84.0 & 74.9 & 57.4 & 89.5 \\
\hline n18:2 & 13.8 & ND & 6.1 & 2.3 & 14.6 & ND \\
\hline 11,12cy19:0 & 1.5 & ND & ND & ND & ND & ND \\
\hline
\end{tabular}

\footnotetext{
${ }^{a} \mathrm{ND}$, not detected.
} 
complete 16S rRNA sequences generated in this study for ACM $2844^{\mathrm{T}}$, ACM 2721, E. longus OCh $101^{\mathrm{T}}$, and Roseobacter denitrificans $\mathrm{OCh} 114^{\mathrm{T}}$. Evolutionary distance values used for tree generation are shown in Table 3. rRNA and rDNA sequencing gave complete agreement.

A total of 1,168 positions were used for phylogenetic comparison. Signature sequences and secondary structural features at the stems from positions 180 to 220 and 455 to 480 show clearly that our isolates are related to members of the $\alpha$ subdivision of the class Proteobacteria $(35,48,59)$. Strains ACM $2844^{\mathrm{T}}$ and ACM 2721 both showed a closer relationship to $E$. longus (evolutionary distance, less than 0.035 [Table 3]; the similarity of complete sequence of ACM $2844^{\mathrm{T}}$ to $E$. longus is $92.6 \%$ ) than to any other member of the data set, and these strains together with $E$. longus form an isolated group ( $\alpha-4)$ within the $\alpha$ subclass (59). They show no close relationship to other bacteriochlorophyll-synthesizing or budding bacteria, including Roseobacter denitrificans (synonymous with Erythrobacter strain OCh 114), and are also, as expected for a member of the Proteobacteria, very distant from the representative planctomycete Pirellula staleyi. Partial sequences for strains ACM 2508 and ACM 2847 showed greater than $98 \%$ sequence similarity to ACM $2844^{\mathrm{T}}$ and hence were not included in the phylogenetic analysis. Our isolates could be distinguished from $E$. longus on the basis of signature sequences at positions 738 to 747 and 1254 to 1280 , which were conserved not only in the four study strains, ACM $2844^{\mathrm{T}}$, ACM 2847, ACM 2721, and ACM 2508, but also in 10 other isolates of similar bacteria from southeast Queensland (unpublished data). These freshwater strains tended to cluster together (data not shown) to the exclusion of $E$. longus.

\section{DISCUSSION}

On the basis of distinctive ultrastructural features combined with 16S rRNA sequences, DNA base composition, cellular fatty acid composition, and nutritional data, all our freshwater isolates of aerobic bacteriochlorophyll-synthesizing bacteria are proposed to be members of a new genus, Porphyrobacter, with type species $P$. neustonensis, comprising the three strains ACM $2844^{\mathrm{T}}$, ACM 2847, and ACM 2508 (ACM 2721 is an allied but distinct strain). The freshwater $P$. neustonensis is a close relative of the marine $E$. longus, and these genera form the $\alpha-4$ group of the $\alpha$ subclass of the Proteobacteria. However, they may be distinguished readily on the basis of $16 \mathrm{~S}$ rRNA sequences, and the consistent genotypic and phenotypic separation of the two taxa warrants their placement in separate genera. Since there is no standard phylogenetic distance defining taxonomic ranks, other data must be used for assigning these strains to separate taxa of appropriate rank. On the basis of the $\mathrm{G}+\mathrm{C}$ content of their genomic DNA, the genera are easily separated, since $E$. longus $\mathrm{OCh}_{101^{\mathrm{T}}}$ has a $\mathrm{G}+\mathrm{C}$ content of $57.4 \mathrm{~mol} \%$ (40), while the Porphyrobacter type strain has a $\mathrm{G}+\mathrm{C}$ content of $66.4 \mathrm{~mol} \%$. They share the trait of aerobic bacteriochlorophyll synthesis but can be distinguished on the basis of chemotaxonomic and phenotypic data. More similar on the basis of $\mathrm{G}+\mathrm{C}$ content is the freshwater aerobic bacteriochlorophyll synthesizer " $E$. sibericus," but no 16S rRNA sequence data exist for that species and thus its phylogenetic relationship to $E$. longus has not been established. In addition, it differs from $P$. neustonensis in oxidase and catalase reactions as well as in its in vivo photosynthetic pigment spectrum and requirement for vitamins (61). When compared with members of the $\alpha$ subclass outside the $\alpha-4$ cluster, Porphyrobacter strains are phenotypically most similar to some Rhodopseudomonas species, in that they bud without forming hyphae, sometimes form rosettes, synthesize $\mathrm{BChl} a$, and possess DNA with a $\mathrm{G}+\mathrm{C}$ content within the range indicated for the latter genus (55). The exact mode of budding, intracellular membrane type, and photosynthetic physiology differ, however, and phylogenetically they are distinct, as shown in the present study. Porphyrobacter strains are not closely related to the other described strain of Erythrobacter, OCh 114, which was recently assigned as the type strain of Roseobacter denitrificans (40). Most of the published physiological data pertaining to the photosynthetic abilities and apparatus of Erythrobacter species refer to this strain rather than to $E$. longus (e.g., references $10,11,14$, and 42). Sequence data generated in the present study show Roseobacter denitrificans to branch separately from the cluster of E. longus and Porphyrobacter strains; it branches more closely to the marine $16 \mathrm{~S}$ rRNA sequence SAR 83, known only from 16S rDNA sequence retrieval via cloning from bacterioplankton genomic DNA of Sargasso Sea seawater, confirming phylogenetic results of the original study that revealed the SAR 83 sequence (2).

Although Porphyrobacter strains possess ultrastructural characters such as crateriform structures and multifibrillar stalklike or fasciclelike structures resembling those characteristic of budding eubacteria in the order Planctomycetales, they are phylogenetically only remotely related to the planctomycetes. Correlated with this absence of evolutionary relationship are the differences in the chemistry of the cell wall and the sensitivity to antibiotics directed against the synthesis of peptidoglycan $(9,16)$. Thus, the occurrence of noncellular stalklike structures and of crateriform structures combined with budding reproduction in Porphyrobacter strains appears to be an interesting example of phenotypic convergence, perhaps reflecting habitat similarities, rather than a reflection of phylogenetic relationship. The utility of $16 \mathrm{~S}$ rRNA sequencing employed here as a tool to resolve several possibilities of relationship is clearly demonstrated by the solution of the problem posed by superficial phenotypic resemblance to planctomycetes.

Cellular fatty acids. The strains examined for cellular fatty acids could be separated into three groups on the basis of the resulting profiles. These groups correlated well with the phylogenetic 16S rRNA sequence analysis. Roseobacter denitrificans (formerly Erythrobacter sp. strain OCh 114) was characterized by an extremely high proportion ( $89 \%$ of total fatty acids) of octadecenoic acid (18:1) and very few other detectable fatty acids. Those strains which clustered together as the $\alpha-4$ subclass in the phylogenetic analysis again showed a close relationship to each other, forming a second and third group with similar profiles. The second group comprised the marine strain $E$. longus, and the third group comprised the freshwater Porphyrobacter strains ACM $2844^{\mathrm{T}}$, ACM 2847, and ACM 2508 . These groups could be distinguished on the basis of the minor components of their fatty acid profiles. One of the Porphyrobacter strains classified on the basis of 16S rRNA sequencing, ACM 2721, could not be definitively placed either with the other Porphyrobacter strains or with $E$. longus on the basis of fatty acid profile. It lacked 18:2 and possessed a second major fatty acid, heptadecenoic acid $(17: 1)$, found only at low levels or not at all in the other strains. Other aerobic bacteriochlorophyll-synthesizing proteobacteria, such as Methylobacterium species, were not included in this study. However, published results for such strains (57) demonstrate 


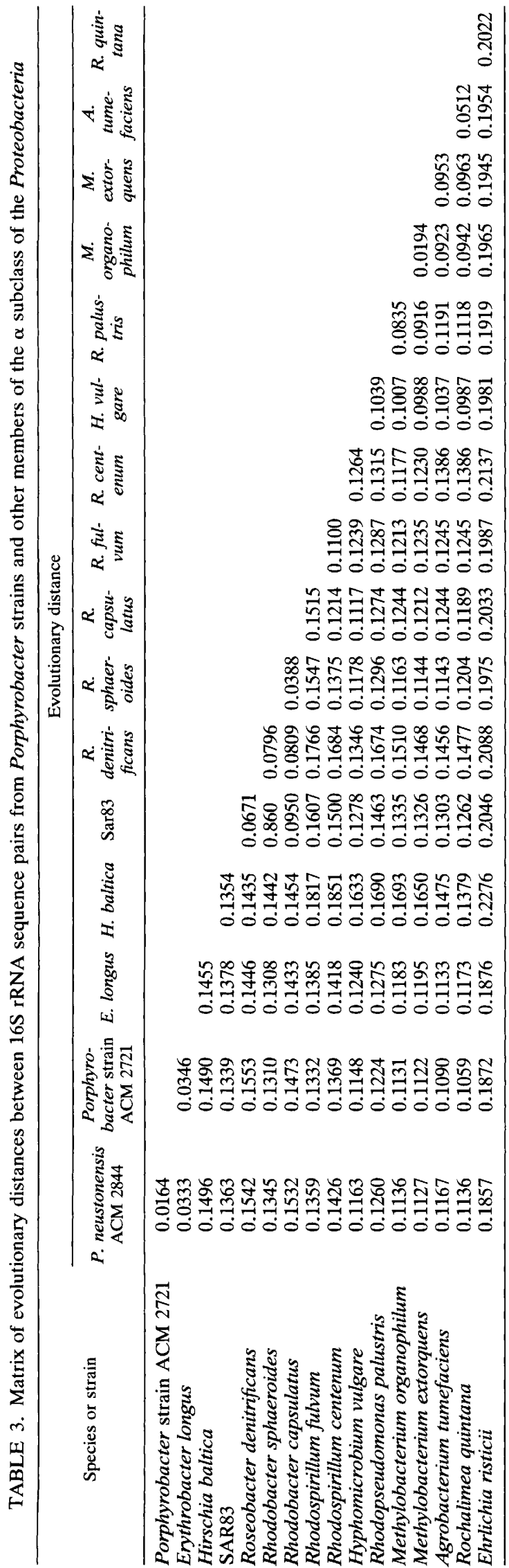

no close similarities in fatty acid profiles for Porphyrobacter and Methylobacterium spp. Given the rarity of diunsaturated fatty acids in bacteria, the 18:2 compound may prove to be a useful marker for the $\alpha-4$ group of the Proteobacteria; that is, Erythrobacter and Porphyrobacter spp. 18:2 fatty acids have also been found in Hirschia, Gemmobacter, Blastobacter, and Campylobacter spp. $(22,31,35)$ but not at such high levels. Its absence from ACM 2721 suggests limits to its usefulness for identifying members of the $\alpha-4$ subclass, however. It should be noted that salt concentration can affect bacterial fatty acid content (51), and this limits the use of this type of data to infer evolutionary relationships. There is no growth medium common to both strains to allow culture under identical salt conditions.

Photosynthetic pigments. Like several other members of the $\alpha$-subdivision of the Proteobacteria, including the aerobic photosynthetic bacteria $E$. longus and Roseobacter denitrificans, Porphyrobacter strains synthesize BChl $a$ when grown aerobically. In vitro spectra displaying ca. $770-\mathrm{nm}$ peaks are consistent with the presence of $\mathrm{BChl} a$, as is the bacteriophaeophytin peak at $748 \mathrm{~nm}$ observed on acidification (25). The presence of peaks in the region of 800 and 870 $\mathrm{nm}$ in the in vivo spectra of sonicated extracts of Porphyrobacter strains is consistent with the presence of $\mathrm{BChl}$ $a$-protein complexes (28), and these peaks are similar but not identical to those found in in vivo (sucrose suspensions) spectra of cell suspensions of $E$. longus (41), which exhibited a major peak at 863 to $867 \mathrm{~nm}$, and differ from those found for "E. sibericus," which possessed a major peak at $863 \mathrm{~nm}$, a minor peak at $875 \mathrm{~nm}$, and a shoulder at $817 \mathrm{~nm}(61)$.

Conclusions. Our four isolates cannot be assigned to any of the previously described genera of aerobic bacteriochlorophyll-synthesizing bacteria. Despite some ultrastructural similarities with members of the Planctomycetales, our strains are clearly members of the class Proteobacteria and are phylogenetically distant, as is this class as a whole, from the planctomycetes. $16 \mathrm{~S}$ rRNA sequence data indicate that these bacteria share a position within the $\alpha-4$ subclass of the Proteobacteria with E. longus. However, they are distinguishable in their 16S rRNA sequences from $E$. longus and differ from $E$. longus in DNA base composition and the following characteristics: Porphyrobacter strains do not require vitamins for growth, in contrast to the biotin-requiring $E$. longus; cannot utilize acetate, glutamate, or butyrate or hydrolyze gelatin; and are all cytochrome $c$ oxidase negative. There are slight quantitative differences in cellular fatty acids between Porphyrobacter strains and $E$. longus, namely consistently higher amounts of 3-hydroxy iso undecanoic acid (3-OH i11:0) and 2-hydroxytetradecanoic acid (2-OH n14:0) and lower amounts of hexadecanoic acid (16:0) in Porphyrobacter strains and detectable though small amounts of n10:0 in Porphyrobacter strains.

Description of Porphyrobacter gen. nov. Porphyrobacter (Por.phy.ro.bac.ter. Gr. adj. porphyreos, purple; Gr. n. bacter, rod; M.L. masc. n. Porphyrobacter, porphyrinproducing rod, referring to bacteriochlorophyll production). Gram-negative pleomorphic motile rods or cocci, reproducing by polar growth or budding. Capable of producing multifibrillar stalklike fascicle structures and crateriform structures on the cell surface. Aerobic. Chemoheterotrophic. Synthesizes BChl $a$ on low-nutrient media under aerobic and semiaerobic conditions. DNA base composition is 65.7 to $66.4 \mathrm{~mol} \% \mathrm{G}+\mathrm{C}$ (by thermal denaturation). Member of the $\alpha-4$ group of the $\alpha$ subclass of Proteobacteria. The type species is $P$. neustonensis.

Description of Porphyrobacter neustonensis sp. nov. Porphy- 
robacter neustonensis (neu.sto.nen'sis M.L. masc. adj. derived from Gr. n. neustos, swimming [floating], referring to occurrence of the bacterium as a member of the neuston [organisms floating at the air-water interface surface layer of a body of water]). Colonies pigmented orange or red. Octadecenoic acid (18:1) is the major cellular fatty acid. Utilizes glucose, galactose, maltose, mannose, sucrose, xylose, arginine, glutamine, and proline as sole carbon sources; does not utilize acetate, glutamate, or butyrate or require vitamins. Lives at the air-water interface of freshwater subtropical pond. $\mathrm{G}+\mathrm{C}$ content of 65.7 to $66.4 \mathrm{~mol} \%$. Type strain, ACM 2844.

\section{ACKNOWLEDGMENTS}

This research has been funded by the Australian Research Council.

We are indebted to Tsuneo Shiba (Ocean Research Institute, University of Tokyo, Otsuchi, Japan) for Erythrobacter and Roseobacter strains. We thank Rick Webb and Helen Hosmer for excellent technical assistance in thin sectioning and printing of electron micrographs. One of us (J.A.F) performed part of this work in the laboratories of James T. Staley of the Department of Microbiology, University of Washington, Seattle, and Beverly Pierson, University of Puget Sound, Tacoma, Wash. J.A.F. is indebted to the late Alex Van Neerven for his assistance in those laboratories.

\section{REFERENCES}

1. Agabian, N., and B. Unger. 1978. Caulobacter crescentus cell envelope: effect of growth conditions on murein and outer membrane protein composition. J. Bacteriol. 133:987-994.

2. Britschgi, T. B., and S. J. Giovannoni. 1991. Phylogenetic analysis of a natural marine bacterioplankton population by rRNA gene cloning and sequencing. Appl. Environ. Microbiol. 57:1707-1713.

3. Brosius, J., M. L. Palmer, J. P. Kennedy, and H. F. Noller. 1978. Complete nucleotide sequence of a 16S ribosomal RNA gene from Escherichia coli. Proc. Natl. Acad. Sci. USA 75:48014805.

4. Casanova, J. L., C. Pannetier, C. Jaulin, and P. Kourilsky. 1990. Optimal conditions for directly sequencing double-stranded PCR products with Sequenase. Nucleic Acids Res. 18:4028.

5. Embley, T. M., J. Smida, and E. Stackebrandt. 1988. Reverse transcriptase sequencing of $16 \mathrm{~S}$ ribosomal RNA from Faenia rectivingula, Pseudonocardia thermophila and Saccharopolyspora hirsuta, three wall type IV actinomycetes which lack mycolic acids. J. Gen. Microbiol. 134:961-966.

6. Evans, E. R., D. E. Fleischman, H. E. Calvert, P. V. Pyati, G. Alter, and N. S. Subba Rao. 1990. Bacteriochlorophyll and photosynthetic reaction centers in Rhizobium strain BTAi 1. Appl. Environ. Microbiol. 56:3445-3449.

7. Felsenstein, J. 1988. PHYLIP Manual Version 3.2. University Herbarium, University of California, Berkeley.

8. Franzmann, P. D., and V. B. D. Skerman. 1981. Agitococcus lubricus gen. nov., a lipolytic, twitching coccus from freshwater. Int. J. Syst. Bacteriol. 31:177-183.

9. Hammes, W. P., J. Winter, and O. Kandler. 1979. The sensitivity of the pseudomurein-containing genus Methanobacterium to inhibitors of murein synthesis. Arch. Microbiol. 123:275-279.

10. Harashima, K., K. Kawazoe, I. Yoshida, and H. Kamata. 1987. Light-stimulated aerobic growth of Erythrobacter species OCh 114. Plant Cell Physiol. 28:365-374.

11. Harashima, K., M. Nakagawa, and N. Murata. 1982. Photochemical activities of bacteriochlorophyll in aerobically grown cells of heterotrophs, Erythrobacter species (OCh 114) and Erythrobacter longus (OCh 101). Plant Cell Physiol. 23:185-193.

12. Harashima, K., T. Shiba, T. Tosuka, U. Simidu, and N. Taga. 1978. Occurrence of bacteriochlorophyll $a$ in a strain of an aerobic heterotrophic bacterium. Agric. Biol. Chem. 42:16271628.

13. Hayward, A. C. 1964. Bacteriophage sensitivity and biochemi- cal groups in Xanthomonas malvacearum. J. Gen. Microbiol. 35:287-298.

14. Iba, K., K. Takamiya, Y. Toh, and M. Nishimura. 1988. Roles of bacteriochlorophyll and carotenoid synthesis in formation of intracytoplasmic membrane systems and pigment-protein complexes in an aerobic photosynthetic bacterium, Erythrobacter sp. strain OCh114. J. Bacteriol. 170:1843-1847.

15. Jones, H. E., and P. Hirsch. 1968. Cell wall composition of Hyphomicrobium species. J. Bacteriol. 96:1037-1041.

16. König, E., H. Schlesner, and P. Hirsch. 1984. Cell wall studies on budding bacteria of the Planctomyces/Pasteuria group and on a Prosthecomicrobium sp. Arch. Microbiol. 138:200-205.

17. Kovacs, N. 1956. Identification of Pseudomonas pyocyanea by the oxidase reaction. Nature (London) 178:703.

18. Lane, D. J., B. Pace, G. J. Olsen, and N. R. Pace. 1988. Reverse transcriptase sequencing of ribosomal RNA for phylogenetic analysis. Methods Enzymol. 167:138-144.

19. Lascelles, J., and D. Wertlieb. 1971. Mutant strains of Rhodopseudomonas sphaeroides which form photosynthetic pigments aerobically in the dark: growth characteristics and enzymic activities. Biochim. Biophys. Acta 226:328-340.

20. Lyman, J., and R. H. Fleming. 1940. Composition of seawater. J. Mar. Res. 3:134-146.

21. Marmur, J. 1961. A procedure for the isolation of deoxyribonucleic acid from microorganisms. J. Mol. Biol. 3:208-218.

22. Moss, C. W., A. Kai, M. A. Lambert, and C. Patton. 1984. Isoprenoid quinone content and cellular fatty acid composition of Campylobacter species. J. Clin. Microbiol. 19:772-776.

23. Murray, R. G. E., P. Steed, and H. E. Elson. 1965. The location of the mucopeptide in sections of the cell wall of Escherichia coli and other Gram-negative bacteria. Can. J. Microbiol. 11: $547-560$.

24. Nishimura, Y., S. Musaka, H. Iizuka, and K. Shimada. 1989. Isolation and characterization of bacteriochlorophyll-protein complexes from an aerobic bacterium, Pseudomonas radiora. Arch. Microbiol. 152:1-5.

25. Oelze, J. 1985. Analysis of bacteriochlorophylls. Methods Microbiol. 18:257-284.

26. Okamura, K., F. Misumori, O. Ito, K.-I. Takamiya, and M. Nishimura. 1986. Photophosphorylation and oxidative phosphorylation in intact cells and chromatophores of an aerobic photosynthetic bacterium, Erythrobacter sp. strain OCh 114. J. Bacteriol. 168:1142-1146.

27. Olsen, G. J., N. Larsen, and C. R. Woese. 1991. The ribosomal RNA database project. Nucleic Acids Res. 19(Suppl.):20172021.

28. Olson, J. M., and E. K. Stanton. 1966. Absorption and fluorescence spectra of bacterial chlorophylls in situ, p. 381-398. In L. P. Vernon and G. R. Seely (ed.), The chlorophylls. Academic Press, Inc., New York.

29. Pierson, B. K. 1985. Heliothrix oregonensis, gen.nov., sp.nov., a phototrophic filamentous gliding bacterium containing bacteriochlorophyll $a$. Arch. Microbiol. 142:164-167.

30. Pierson, B. K., S. J. Giovannoni, and R. W. Castenholz. 1984. Physiological ecology of a gliding bacterium containing bacteriochlorophyll $a$. Appl. Environ. Microbiol. 47:576-584.

31. Rothe, B., A. Fischer, P. Hirsch, M. Sittig, and E. Stackebrandt. 1987. The phylogenetic position of the budding bacteria Blastobacter aggregatus and Gemmobacter aquatilis gen. nov., sp. nov. Arch. Microbiol. 147:92-99.

32. Rubin, S. J., P. A. Granato, and B. L. Wasilauskas. 1980. Glucose-nonfermenting gram-negative bacteria, p. 263-287. In E. H. Lennette, A. Balows, W. J. Hausler, Jr., and J. P. Truant (ed.), Manual of clinical microbiology, 3rd ed. American Society for Microbiology, Washington, D.C.

33. Saris, P. E. J., L. G. Paulin, and M. Uhlen. 1990. Direct amplification from colonies of Bacillus subtilis and Escherichia coli by the polymerase chain reaction. J. Microbiol. Methods 11:121-126.

34. Sato, K. 1978. Bacteriochlorophyll formation by facultative methylotrophs Protaminobacter ruber and Pseudomonas AM1. FEBS Lett. 85:207-210.

35. Schlesner, H., C. Bartels, M. Sittig, M. Dorsch, and E. Stacke- 
brandt. 1990. Taxonomic and phylogenetic studies on a new taxon of budding, hyphal Proteobacteria, Hirschia baltica gen. nov., sp. nov. Int. J. Syst. Bacteriol. 40:443-451.

36. Schlesner, H., and E. Stackebrandt. 1986. Assignment of the genera Planctomyces and Pirella to a new family Planctomycetaceae fam. nov. and description of the order Planctomycetales ord. nov. Syst. Appl. Microbiol. 8:174-176.

37. Schmidt, J. M. 1978. Isolation and ultrastructure of freshwater strains of Planctomyces. Curr. Microbiol. 1:65-70.

38. Shiba, T. 1984. Utilization of light energy by the strictly aerobic bacterium Erythrobacter sp. OCh114. J. Gen. Appl. Microbiol. 30:239-244.

39. Shiba, T. 1989. Overview of the aerobic photosynthetic bacteria, p. 1-8. In K. Harashima, T. Shiba, and N. Murata (ed.), Aerobic photosynthetic bacteria. Japan Scientific Societies Press, Tokyo and Springer-Verlag, Berlin.

40. Shiba, T. 1991. Roseobacter litoralis gen. nov., sp. nov., and Roseobacter denitrificans sp. nov., aerobic pink-pigmented bacteria which contain bacteriochlorophyll $a$. Syst. Appl. Microbiol. 14:140-145.

41. Shiba, T., and U. Simidu. 1982. Erythrobacter longus gen. nov., sp. nov., an aerobic bacterium which contains bacteriochlorophyll $a$. Int. J. Syst. Bacteriol. 32:211-217.

42. Shimada, K., H. Hayashi, and M. Tasumi. 1985. Bacteriochlorophyll-protein complexes of aerobic bacteria, Erythrobacter longus and Erythrobacter species OCh 114. Arch. Microbiol. 143:244-247.

43. Sierra, G. 1957. A simple method for the detection of lipolytic activity of microorganisms and some observations on the influence of the contact between cells and fatty substrates. Antonie van Leeuwenhoek 23:15-22.

44. Sistrom, W. R., and R. K. Clayton. 1964. Studies on a mutant Rhodopseudomonas sphaeroides unable to grow photosynthetically. Biochim. Biophys. Acta 88:61-73.

45. Skerman, V. B. D. 1967. A guide to the identification of the genera of the bacteria, 2nd ed. The Williams \& Wilkins Co., Baltimore.

46. Sly, L. I., L. L. Blackall, P. C. Kraat, T. Tian-Shen, and V. Sangkhobol. 1986. The use of second derivative plots for the determination of mol\% guanine plus cytosine of DNA by the thermal denaturation method. J. Microbiol. Methods 5:139-156.

47. Sly, L. I., and M. H. Hargreaves. 1984. Two unusual budding bacteria isolated from a swimming pool. J. Appl. Bacteriol. 56:479-486.

48. Stackebrandt, E., R. G. E. Murray, and H. G. Trüper. 1988. Proteobacteria classis nov., a name for the phylogenetic taxon that includes the "purple bacteria and their relatives." Int. J. Syst. Bacteriol. 38:321-325.

49. Staley, J. T. 1981. The genus Pasteuria, p. 490-492. In M. P. Starr, H. Stolp, H. G. Trüper, A. Balows, and H. G. Schlegel (ed.), The prokaryotes: a handbook on habitats, isolation, and identification of bacteria, vol. 1. Springer-Verlag, Berlin.

50. Staley, J. T. 1981. The genera Prosthecomicrobium and Ancalomicrobium, p. 456-460. In M. P. Starr, H. Stolp, H. G. Trüper, A. Balows, and H. G. Schlegel (ed.), The prokaryotes: a handbook on habitats, isolation, and identification of bacteria, vol. 1. Springer-Verlag, Berlin.

51. Sutton, G. C., P. J. Quinn, and N. J. Russell. 1990. The effect of salinity on the composition of fatty acid double-bond isomers and $s n-1 / s n-2$ positional distribution in membrane phospholipids of a moderately halophilic eubacterium. Curr. Microbiol. 20:4346.

52. Takamiya, K., and K. Okamura. 1984. Photochemical activities and photosynthetic ATP formation in membrane preparation from a facultative methylotroph, Protaminobacter ruber strain NR-1. Arch. Microbiol. 140:21-26.

53. Tautz, D., and M. Renz. 1983. An optimised freeze-squeeze method for the recovery of DNA fragments from agarose gels. Anal. Biochem. 132:14-19.

54. Tekniepe, B. L., J. M. Schmidt, and M. P. Starr. 1981. Life cycle of a budding and appendaged bacterium belonging to morphotype IV of the Blastocaulis-Planctomyces group. Curr. Microbiol. 5:1-6.

55. Trüper, H. G., and J. F. Imhoff. 1989. Genus Rhodopseudomonas Kluyver and van Niel in Czurda and Maresch 1937, 119 p. 1672-1677. In J. T. Staley, M. P. Bryant, N. Pfennig, and J. G. Holt (ed.), Bergey's manual of systematic bacteriology, vol. 3. The Williams \& Wilkins Co., Baltimore.

56. Tsuji, K., H. C. Tsien, R. S. Hanson, S. R. DePalma, R. Scholtz, and S. LaRoche. 1990. 16S ribosomal RNA sequence analysis for determination of phylogenetic relationship among methylotrophs. J. Gen. Microbiol. 136:1-10.

57. Urakami, T., and K. Komagata. 1987. Cellular fatty acid composition with special reference to the existence of hydroxy fatty acids in gram-negative methanol-, methane-, and methylamineutilizing bacteria. J. Gen. Appl. Microbiol. 33:135-165.

58. Weisburg, W. G., S. M. Barns, D. A. Pelletier, and D. J. Lane. 1991. 16S ribosomal DNA amplification for phylogenetic study. J. Bacteriol. 173:697-703.

59. Woese, C. R., E. Stackebrandt, W. G. Weisburg, B. J. Paster, M. T. Madigan, V. J. Fowler, C. M. Hahn, P. Blanz, R. Gupta, K. H. Nealson, and G. E. Fox. 1984. The phylogeny of purple bacteria: the alpha subdivision. Syst. Appl. Microbiol. 5:315326.

60. Yildiz, F. H., H. Gest, and C. E. Bauer. 1991. Attenuated effect of oxygen on photopigment synthesis in Rhodospirillum centenum. J. Bacteriol. 173:5502-5506.

61. Yurkov, V. V., and V. M. Gorlenko. 1990. Erythrobacter sibericus sp. nov., a new freshwater aerobic bacterial species containing bacteriochlorophyll $a$. Microbiology 59:85-89. (Translation from Mikrobiologiya 59:120-126.) 